\title{
THE ANALYSIS OF MARBLE INDUSTRY IN AFGHANISTAN, CASE STUDY OF NANGARHAR PROVINCE
}

\author{
Mohammad Zubair Noormel \\ Lecturer in Economics Department \\ Nangarhar University, Nangarhar, Afghanistan
}

\begin{abstract}
The marble industry is one of the fastest growing sectors of Afghan's economy (Kuo., 2012; Rassin, 2012). Currently 40 marbles are being quarried, and over a hundred more have been identified and catalogued, and therefore supply is not a major constraint on growth. Current growth is two-pronged; the industry is gaining increased share of the domestic market for low-cost marbles, while expanding exports of high-value marbles that are in demand worldwide.
\end{abstract}

Afghanistan is home to 60 known deposits, and it is projected that there are as many as 400 varieties of marble. With numerous high-quality deposits, the Afghanistan dimension stone industry has great potential to become a significant player in the Afghan economy and provide thousands of rural jobs at the quarries and in the downstream processing industry. Among the province of Afghanistan, Nangarhar province has rich natural resources including marble, wood, and gemstone deposits which are using locally and exports to other countries. Furthermore, Nangarhar is well known as the center base of uncut marble in the country and has excellent geological possibility and growth for a greater production of marble stones. By considering the importance of the sector, this study intended to analyze the sector status by collecting primary data from 13 big marble producers. The result of the study showed most of the producers are engaged as a family business and there is no huge investment as partnership or big industrial company in the sector. Furthermore, the employment level along with the sales are very low in the industry, the reason behind it, are foreign marble products which are competing with local producers and not letting the local producer to grow, sale, and hire more. The main biggest problems which is mentioned by the producers were lack of infrastructure, lack of electricity, limitation of raw materials' extractions, damping policies of other countries, and higher taxes.

Keywords - Marble Industry, Production process, Energy sources, Investment. Competition

\section{RESEARCH QUESTION/THEORETICAL CONTEXTUALIZATION}

Afghanistan which is the fourth largest Country in South Asia after India, Pakistan, and Bangladesh, is considered poor landlocked which is currently recovering from several decades of war. The war and conflicts destroyed the infrastructure and brought destruction to the economic infrastructure. With the fall of Taliban regime in 2001, with the help of international community the economy of the country has improved considerably, and the focus on investment was taken up with full energy immediately. New regime of Afghanistan has chosen free market economy for businesses. At the same time the Afghan government start focusing on improvement of investment in different sectors and in different provinces by inviting FDIs and local investors (Chossudovsky, 2013).

Huge investment has been done in different sectors and industry which among them are marble industry as Afghanistan has great potential in this sector by having huge mountains which can be the biggest source of raw material for the sector.

Afghanistan is hub to 60 known deposits and it is projected that there are as many as 400 varieties of marble in the country. With numerous high-quality deposits, the Afghanistan dimension stone industry has great potential to become an important player in the Afghan economy. Furthermore, it will provide thousands of rural jobs at the quarries and in the downstream processing industry. The quality and quantity of Afghan marble deposits delivers a comparative advantage which the industry can influence to gain competitive advantage. As an example, we can take in consideration the deposits in Chesht and Khogiani districts which has top-quality white marble very similar to Cararra marble from Italy. The buyers from Gulf Countries, U.S., Italy are already buying this marble and demand for the marble exceeds available supply. Currently, nine white cities are being created in Turkmenistan using Afghanistan white marble which has replaced imports of Italian marble. As perhaps the only source of high-quality white marble in the region, Afghanistan enjoys a 


\section{International Journal of Engineering Applied Sciences and Technology, 2019 \\ Vol. 4, Issue 5, ISSN No. 2455-2143, Pages 82-87 \\ Published Online September 2019 in IJEAST (http://www.ijeast.com)}

comparative advantage with other regional competitors based on the availability of raw materials and with respect to Italy as a result of its proximity to market. The high value of the marble will cover the higher costs of any inefficiency while the enterprises fine tunes their operations. Besides Chesht and Khogiani, numerous other deposits with export potential have been identified.

Afghanistan annual marble production in the year 2012 was shown around 124,000 to 155,000 tons. But over half of unprocessed marble goes to Pakistan and Iran which are Afghanistan's neighbors. Total consumption of finished marble in Afghanistan was estimated around 270,000 tons. Pakistani marble dominated 80 to 85 percent of Afghan marble market. Currently the total value added of the Afghan marble industry is around $\$ 105$ million which makes 0.6 percent of GDP According to the Minister of Mines, Wahidullah Shahrani, "Afghanistan marble claims more than 100 high quality diversities, in different spanning, colors, and patterns. Based on the data published by US embassy, Afghanistan marble exports reached at $\$ 15$ million per year. With updated extraction methods, processing availabilities, infrastructure, and new investments, the industry has the potential to grow into value of $\$ 450$ million per year (US embassy, 2010).

In Afghanistan there are 31 active quarries, 72 processing plants and over 100 small-scale handicraft units and 4000 to 5000 people are directly employed in this industry. The overall growth rate of the marble industry in term of production is around 60 percent per annum. This is due to the fact that Afghan marble industry has been recently reinvented. But the growth rate of 60 percent is not evenly spread over all marble firms (AISA Report, 2012).

Nangarhar province is located on the eastern side of Afghanistan and have border with Laghman and Kunar provinces to the North, Kabul, Logar and Paktya in the West side, and $75 \mathrm{Km}$ an international border (Durand Line) with Pakistan. Nangarhar province geographic location is close to the Pakistan border which gives it an obvious economic benefit over neighboring centers of trade. Currently, many of its potential economic opportunities are only partially being explored in the market and it has considered as a vital province for Afghanistan economy. The province has great potential for marble industry and endowed with a lot of natural resources. In some of the districts of the province there are huge mines of highquality marbles which are used locally and also exported to other countries. Large number of firms working on marble industry is locating in Nangarhar as the province has rich resources of marbles and other stones which are used locally and also exported to other countries, however the sector is not well managed and has gap of development to be filled (Yahya, 2009).

In Nangarhar the industry is facing huge challenges due to unavailability of processing facilities. In Nangarhar most of the sites use low tech, wasteful, explosive-based extraction to remove marble which is then typically transported to Pakistan for cutting and polishing. Most of the value in production of marble is created in the final two steps which is typically done in Pakistan.

\section{DESCRIPTION OF DATA}

As the study intended to analyze the current status of marble industry in Nangarhar province which include the type of business, type of problems the industry faces,...etc., therefore primary data from important and big producers of marble being collected. The primary data was collected through interview by using structured questionnaire. The number of producers being interviewed are 13 biggest producers which are located in different parts of Nangarhar province.

\section{RESEARCH QUESTION}

By considering importance of the sector, this study intended to find answers to the following important questions.

- Which market characteristics does Nanagahar marble industry have?

- Which underlying problems that curb potential growth of the industry exist in the production of marble in Nangarhar?

- How profitable is the industry from investors perspective?

- How is the overall picture of marble industry in Nangarhar?

\section{FIELD RESEARCH DESIGN/ METHODS OF DATA GATHERING}

The data were concluded from both primary and secondary sources. Primary data was collected in the field by interviewing 13 marble producers. The research based primary data was collected from the randomly selected respondents which are considered to be the biggest producer of marble in the province. The data were collected through interview by using structured questionnaire. Most of the producers targeted in interview were locating in the districts near to Jalalabad city.

\section{RESULTS}

As mentioned in the previous sections, the data has been collected with the help of structured questionnaire from 13 big marble producers. After the collection of data, it has been sorted and descriptively 


\section{International Journal of Engineering Applied Sciences and Technology, 2019 \\ Vol. 4, Issue 5, ISSN No. 2455-2143, Pages 82-87 \\ Published Online September 2019 in IJEAST (http://www.ijeast.com)}

or qualitatively analyzed which the result being presented step by step.

Among the interviewed marble producer 84.6 percent of the producers were running their own or family business and only 15.4 percent of the business were partnership.

\section{TYPE OF BUSINESS}

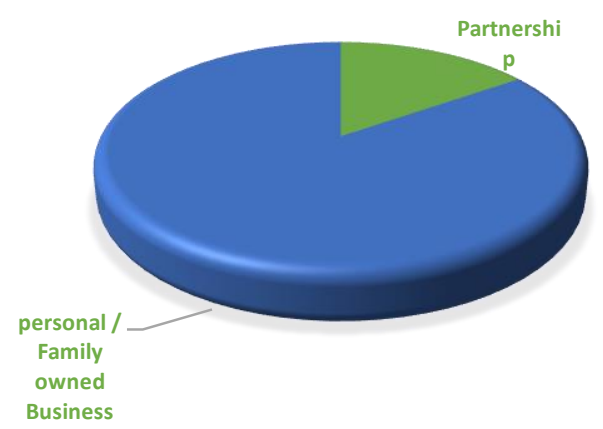

The years of experience that the marble producers had in the market were not high. The average experience years among the producers were 8.5 years and only two producers had 16 years of experience.

The average monthly production value of the marble produced in Nangarhar is 132,000 Afghani (AFN) which is almost 1,700 US dollar (USD). Only one producer was producing marble with the value of 400,000 per month and the rest 10 producers were producing marble with value of less than 200,000 AFN.

The marble sector in the province is very famous and it looked that large number of people would be busy in the industry, however on average each producer had 13 employee which is less for such scale production. Furthermore, in majority of cases the family member of the producer is busy in the business and working more than 10 hours per day, which as a result they are not hiring more employees.

Among the surveyed producer 69 percent of them were producing Afghan white marble type and 8 percent of them were interested in Pakistani type. Among the surveyed producer 3 of them did not answer the question regarding their product type.

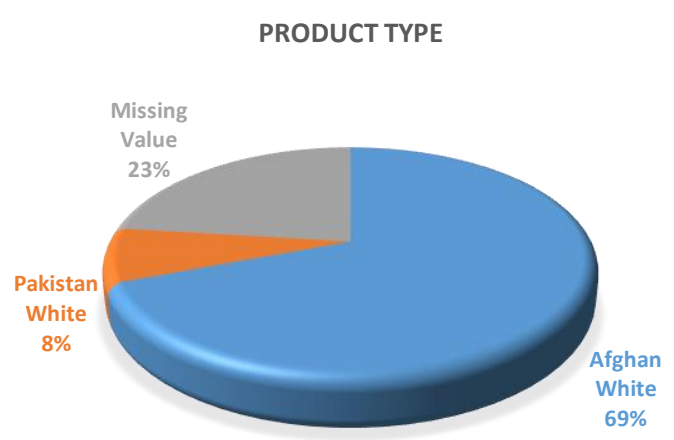

When the question being asked regarding competition problem, the producer named lower price and product diversity as a major winning point of the foreign competitors from them, however more than 55 percent of the producers were claiming that they have better quality than other countries producers competing in the market. The major countries which are competing in Afghan marble industry are Pakistan, Iran, and China. Furthermore, the Afghan producers of marble claiming that the above countries are doing damping in order to close their business. 92 percent of the Afghan producers were claiming that they are suffering from damping policies of Pakistan, Iran and China which made for them difficult to survive in the industry, they were further claiming that the foreign competitors are receiving tax allowance and subsidy from their governments to take over the Afghan marble market.

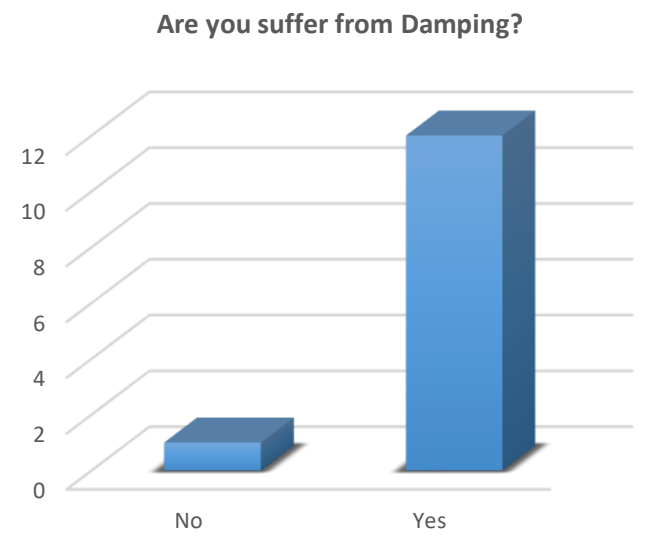

Afghan marble producers were not satisfied of government work and policies for the industry, and they were complaining that most of the time they are being affected negatively by some of the government policies.

Which governement policies effected your business?

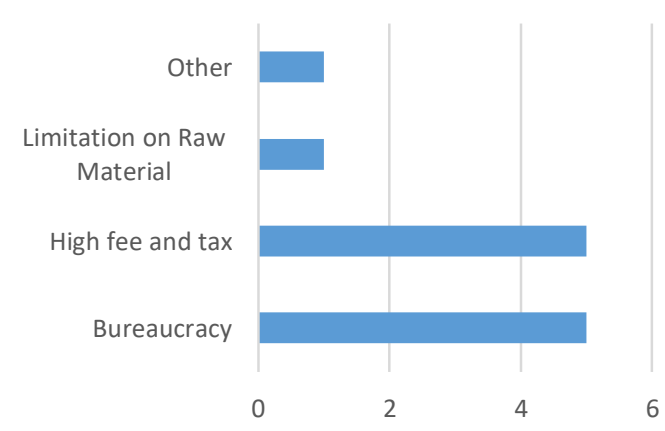




\section{International Journal of Engineering Applied Sciences and Technology, 2019 \\ Vol. 4, Issue 5, ISSN No. 2455-2143, Pages 82-87 \\ Published Online September 2019 in IJEAST (http://www.ijeast.com)}

Most of them criticized government's tax policies along with bureaucratic system of the government which affected their business in a bad way. Furthermore, some of the producers were mentioning limits on extraction of raw material from the sites which imposed by government. Other problems which created by government and mentioned by producers were, asking for illegal payment, fee of electricity, and leaving the market for competitors very open. Moreover, the producers were claiming that Afghan government and local government are not looking to the industry positively, therefore they are not taking any step to support them by providing them different facilities.

During the survey some of the question regarding their products and customers were also asked. General people were for 46.2 percent of the producers were the target customer, however some of them were producing only for local retailers (7.7 percent) and specific customers (7.7 percent). Interesting point were that 15 percent of the producers did not know whom they are targeting, they were generally selling to everyone who asked them.

The monthly sales of the producers are not as high as it is expected. The average value of monthly sale reached to $87,857 \mathrm{AFN}$ which is almost equal to 1,200 USD. It is important to mention that among 13 producers only 7 of them answered the question of monthly sale. The rest were not giving the value, due to future problem with tax collection authorities.

\begin{tabular}{|l|l|c|}
\hline \multicolumn{2}{|c|}{ Statistics } \\
\hline \multirow{2}{*}{$\mathrm{N}$} & Vales per month in AFN \\
\cline { 2 - 3 } & Missing & 7 \\
\hline \multirow{2}{*}{ Mean } & 6 \\
\hline \multirow{2}{*}{ Minimum } & $87,857.14$ \\
\hline Maximum & 25,000 \\
\hline
\end{tabular}

The raw material which are using for marble production is brought from different sources. More

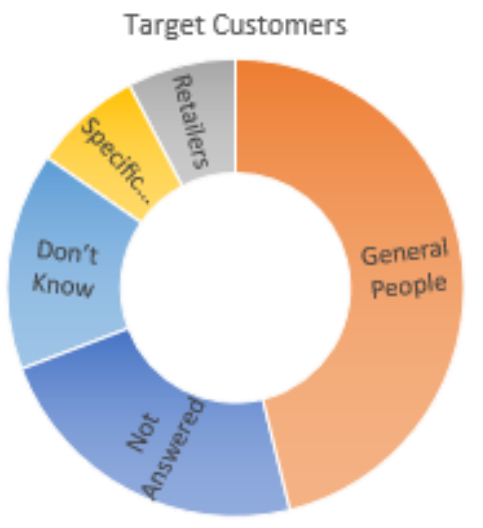

than 40 percent of the producers bring their raw material from Nangarhar itself, Kabul, and Wardak province of Afghanistan.

However, most of the producers first were using Nangarhar marble raw material. While they are extracting raw material for processing, the government sat a limit on daily and monthly extraction of raw material. This policy of government is not allowing the producers to take advantage of economies of scale by producing more, as fixed cost of marble production is higher than the variable costs.

\begin{tabular}{|c|c|c|}
\hline \multicolumn{3}{|c|}{ Statistics } \\
\hline \multicolumn{3}{|c|}{ Profit Margin in Percentage } \\
\hline \multirow[t]{2}{*}{$\mathrm{N}$} & Valid & 13 \\
\hline & Missing & 0 \\
\hline \multicolumn{2}{|c|}{ Mean } & 8.92 \\
\hline \multicolumn{2}{|c|}{ Minimum } & 0 \\
\hline \multicolumn{2}{|c|}{ Maximum } & 15 \\
\hline
\end{tabular}

The profit margin that the producers has is on average 8.92 percent which is very low by considering the sales level.

\section{Source of Raw Material}

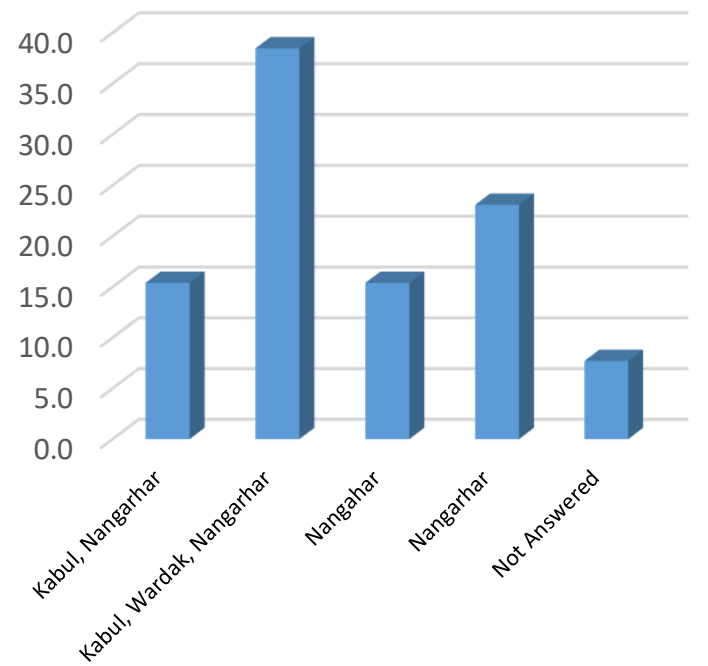

The reason behind having low margin of profit is foreign competitors with lower prices. When the local producers increase their profit margin then the prices will go higher than the prices of foreign marble producers and as a result, they will not be able to sale their product.

Currently the whole market is focused on price competition, however Afghan producers are producing in better quality as they have world best raw material. But due to lack of government support they 


\section{International Journal of Engineering Applied Sciences and Technology, 2019 \\ Vol. 4, Issue 5, ISSN No. 2455-2143, Pages 82-87 \\ Published Online September 2019 in IJEAST (http://www.ijeast.com)}

are not able to increase their prices and earn more profit from the marble production.

\begin{tabular}{|c|c|c|c|c|c|c|c|}
\hline \multirow[b]{2}{*}{ 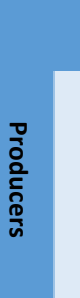 } & \multicolumn{7}{|c|}{$\begin{array}{l}\text { Do the following Uncertainties created problems for } \\
\text { your business? }\end{array}$} \\
\hline & 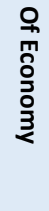 & 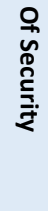 & 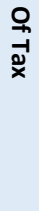 & 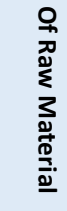 & 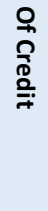 & 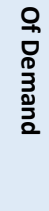 & 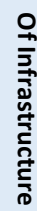 \\
\hline 1st & $v$ & V & $v$ & $\mathrm{~V}$ & $v$ & $\mathrm{~V}$ & \\
\hline 2nd & & $v$ & $v$ & V & $v$ & & \\
\hline \multicolumn{8}{|l|}{ 3rd } \\
\hline 4th & V & V & V & V & V & V & \\
\hline 5th & & V & & & & & \\
\hline 6th & $v$ & $v$ & 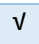 & V & $v$ & $v$ & \\
\hline 7th & $v$ & V & $\sqrt{ }$ & V & & $v$ & $v$ \\
\hline 8th & $v$ & $v$ & $v$ & V & $v$ & $v$ & \\
\hline 9th & $v$ & $v$ & 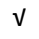 & $v$ & & & \\
\hline 10th & $v$ & V & $\sqrt{ }$ & $v$ & $v$ & $v$ & \\
\hline 11th & V & V & V & $v$ & $v$ & & \\
\hline 12th & $v$ & V & $\sqrt{ }$ & $\mathrm{V}$ & $v$ & $v$ & 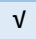 \\
\hline 13th & V & $\mathrm{V}$ & V & $v$ & $v$ & $v$ & \\
\hline
\end{tabular}

Most of the producers were affected from the uncertainties of the market to enlarge their business and make new investment. In the above matrix table, the uncertainties which is listed by producers are being shown which uncertainty in economy, security, availability of raw material, and taxes system are the highest selected ones.

\section{DISCUSSIONS}

One of the fastest growing industry in Afghanistan which large number of investors are interested in, is the marble industry. Currently 40 marbles are being quarried, and over a hundred more have been identified and catalogued, and therefore supply is not a major constraint on growth. Current growth is twopronged; the industry is gaining increased share of the domestic market for low-cost marbles, while expanding exports of high-value marbles that are in demand worldwide.

Afghanistan is home to 60 known sources of marble, and it is estimated that there are as many as 400 varieties of marble in the country. With numerous high-quality deposits, the Afghanistan dimension stone industry has great potential to become a significant player in the Afghan economy and provide thousands of rural jobs at the quarries and in the downstream processing industry. Large number of firms working on marble industry is locating in Nangarhar as the province has rich resources of marbles and other stones which are used locally and also exported to other countries. However, in Nangarhar the industry is facing huge challenges due to different problems. The result of the study showed most of the producers are engaged as a family business and there is no huge investment as partnership or big industrial company in the sector. Furthermore, the employment level along with the sales are very low in the industry, the reason behind it are foreign marble products which are competing with local producers and not letting the local producer to grow and sale and hire more. The main biggest problems which is mentioned by the producers were lack of infrastructure, electricity, limitation of raw materials, damping policies of other countries' producers, higher taxes, and other costs which most of the problems could be solved by rational actions of the government. The Afghan government should facilitate electricity and industrial land for the producers with lower tax and other subsidies, in order to make local producer capable of competing with foreign exporters. Furthermore, the government could give privilege to the local producers in governmental contracts, which at the end would help the government in increasing employment and earn more money as a result of new investments in the sector.

\section{REFERENCES}

- Rassin, A. G. (2012). A comprehensive study of marble industry in Afghanistan. Research \& Statistics Department Afghanistan Investment Support Agency.

- Kuo, C. S. (2012). The mineral industry of Afghanistan. Area Reports: International Review: 2010, International, Asia and the Pacific, 1.

- Chossudovsky, M. (2013). The War is Worth Waging": Afghanistan's Vast Reserves of Minerals and Natural Gas. Global Research.

- Yahya, M. (2009). Afghanistan's Marble Industry Competitiveness (Doctoral dissertation, Thesis. Robert Kennedy College, 2009. Print).

- AISA Report. (2012). Essential facts on economic performance and investment in Afghanistan.

- Mulk, S., Azizullah, A., Korai, A. L., \& Khattak, M. N. K. (2015). Impact of marble industry effluents on water and sediment quality of Barandu River in Buner District, Pakistan. Environmental monitoring and assessment, 187(2), 8.

- $\quad$ Akbar, F., Hadi, F., Ullah, Z., \& Zia, M. A. (2007). Effect of marble industry effluent on seed germination, post germinative growth and productivity of Zea mays L. Pak. J. Biol. Sci, 10, 4148-4151. 
- $\quad$ Bassir, S. H. (1995). Equipment selection in the Iranian marble quarries (dimension-stone industry): Procedures and problems. Proceedings of Mine Planning and Equipment Selection, Singhal et al.(eds), Balkema, Rotterdam, 357-361.

- Khodabakhshian, A., Ghalehnovi, M., De Brito, J., \& Shamsabadi, E. A. (2018). Durability performance of structural concrete containing silica fume and marble industry waste powder. Journal of cleaner production, 170, 42-60.

- Rassin, A. G. (2012). a comprehensive study of Marble industry in Afghanistan. Research \& Statistics Department Afghanistan Investment Support Agency.

- Mitchell, C., \& Benham, A. (2008). Afghanistan: revival and redevelopment. Industrial Minerals, 489, 5863.

- Bhandari, B. K., \& Jogezai, G. (2013). Afghanistan in SAARC: Emerging opportunities in regional integration. 